\title{
Cellular senescence in naevi and immortalisation in melanoma: a role for $\mathrm{p} 16$ ?
}

\section{VC Gray-Schopfer ${ }^{1,2}$, SC Cheong ${ }^{1,7}$, H Chong ${ }^{3}$, J Chow ${ }^{3}$, T Moss ${ }^{4}$, ZA Abdel-Malek ${ }^{5}$, R Marais ${ }^{2}$, D Wynford-Thomas ${ }^{6}$ and DC Bennett*,I}

'Division of Basic Medical Sciences, St George's, University of London, Cranmer Terrace, SWI 7 ORE, UK; ${ }^{2}$ The Institute for Cancer Research, London SW3 6JB, UK; ${ }^{3}$ Division of Cellular and Molecular Medicine, St George's, University of London, London SWI7 ORE, UK; ${ }^{4}$ Department of Plastic Surgery, St George's Hospital, London SWI 7 OQT, UK; ${ }^{5}$ Department of Dermatology, University of Cincinnati, Cincinnati, OH 45267, USA; ${ }^{6}$ Department of

Pathology, University of Wales College of Medicine, Cardiff, UK

Cellular senescence, the irreversible proliferative arrest seen in somatic cells after a limited number of divisions, is considered a crucial barrier to cancer, but direct evidence for this in vivo was lacking until recently. The best-known form of human cell senescence is attributed to telomere shortening and a DNA-damage response through p53 and p21. There is also a more rapid form of senescence, dependent on the p 16 -retinoblastoma pathway. pl6 (CDKN2A) is a known melanoma susceptibility gene. Here, we use retrovirally mediated gene transfer to confirm that the normal form of senescence in cultured human melanocytes involves $\mathrm{p} / 6$, since disruption of the pl6/retinoblastoma pathway is required as well as telomerase activation for immortalisation. Expression (immunostaining) patterns of senescence mediators and markers in melanocytic lesions provide strong evidence that cell senescence occurs in benign melanocytic naevi (moles) in vivo and does not involve p53 or p2I upregulation, although p I 6 is widely expressed. In comparison, dysplastic naevi and early (radial growth-phase, RGP) melanomas show less pl 6 and some p53 and p2I immunostaining. All RGP melanomas expressed p2I, suggesting areas of p53-mediated senescence, while most areas of advanced (vertical growthphase) melanomas lacked both p16 and p2I, implying escape from both forms of senescence (immortalisation). Moreover, nuclear pl6 but not p2I expression can be induced in human melanocytes by oncogenic BRAF, as found in around $80 \%$ of naevi. We conclude that cell senescence can form a barrier to melanoma development. This also provides a potential explanation of why $\mathrm{p} / 6$ is a melanoma suppressor gene.

British Journal of Cancer (2006) 95, 496-505. doi:I0.I038/sj.bjc.6603283 www.bjcancer.com

Published online I August 2006

(C) 2006 Cancer Research UK

Keywords: cellular senescence; immortalisation; melanoma; naevus; p 16; p53

Cellular senescence, the growth arrest seen in normal mammalian cells after a limited number of divisions, is controlled by key tumour suppressors including p53 and p16, and is believed to be a crucial barrier to tumour development (Sharpless and DePinho, 2004). However, evidence for this overall concept comes very largely from cell cultures and animal models (Wynford-Thomas, 1999; Sherr, 2001; Sharpless and DePinho, 2004). No direct evidence has yet been presented that cell senescence forms a true barrier to development of human cancers in vivo, although improved evidence from animal models has emerged recently (Braig et al, 2005; Collado et al, 2005).

Two main pathways effecting normal cellular senescence in culture have been reported. The best known form of senescence, first described in fibroblasts, is effected primarily by the p53 pathway (Wynford-Thomas, 1999; Sherr, 2001; Sharpless and DePinho, 2004), and can be overcome by expression of exogenous hTERT (human telomerase reverse transcriptase, required for

\footnotetext{
*Correspondence: Professor DC Bennett; E-mail: dbennett@sgul.ac.uk

${ }^{7}$ Present address: The Cancer Research Initiatives Foundation, Selangor, Malaysia

Revised 26 June 2006; accepted 26 June 2006; published online I August 2006
}

telomere maintenance), to give immortal (indefinitely proliferating) cultures (Bodnar et al, 1998). Here, senescence appears to be dependent on limited shortening of telomeres, activating p53 through checkpoint kinases 2 and possibly 1 (CHK2 and CHK1) (Stewart et al, 2003; d'Adda di Fagagna et al, 2003; Von Zglinicki et al, 2005). An alternative route to senescence was reported in certain epithelial cells. It involves only the p16/RB1 pathway, and the cells require interference with this pathway as well as hTERT expression, for immortalisation (Kiyono et al, 1998). p16-dependent senescence was abolished by disruption of the RB1 pathway, after which a further, p53-dependent growth arrest was observed. p16-dependent arrest of epithelial cells was, however, circumvented by culture with growth-inactivated fibroblast 'feeder' cells. The cells showed extended proliferation, p53-dependent senescence, and immortalisation with hTERT alone (Ramirez et al, 2001). The authors suggested that p16-dependent senescence was an artefact of imperfect culture conditions, leading to 'stress' (Ramirez et al, 2001).

In p16-dependent senescence, the cyclin-dependent kinase (CDK) inhibitor p16 is synthesised and activates RB1, by inhibiting phosphorylation of RB1 by CDK4 or CDK6 (Kiyono et al, 1998; Sharpless and DePinho, 2004). p16 is itself a tumour suppressor; germline mutations at its locus $C D K N 2 A$ are principally associated with familial melanoma in humans, with some increased incidence 
of pancreatic cancer, suggesting particular importance in melanocytes (Gruis et al, 1995; Bennett, 2003; Hayward, 2003; Kefford et al, 2004; Gray-Schopfer and Bennett, 2006). In sporadic cancers, p16 alterations and deletions are more broadly distributed, being found in many types of cancer. The COSMIC database of over 13000 cancer samples (Forbes et al, 2006) (http://www.sanger. ac.uk/genetics/CGP/cosmic/) lists p16 point mutations in $15 \%$ of all tested samples, including nearly every cancer type tested, although the frequency varies with type and culture status (22\% for melanoma, $9 \%$ for all uncultured melanoma samples). This does not include deletions, and a recent study by comparative genome hybridisation highlighted p16 as the most commonly deleted gene in uncultured primary melanomas, at $50 \%$ frequency (Curtin et al, 2005). Thus, at least $59 \%$ of uncultured melanomas apparently have a p16 deficiency. To this can be added gene silencing; CDKN2A promoter methylation was reported in $19 \%$ of invasive primary melanomas (Straume et al, 2002). Moreover, a study with melanoma cell lines found that $100 \%$ of lines with normal p16 had a different alteration in the RB pathway (Bartkova et al, 1996). It is not clear how many other cancer types show such high total frequencies of somatic p16 alteration; but even if the specific relation between p16 and melanoma is restricted to germline mutations, it is interesting that there is evidence for the p16dependent form of senescence in human melanocytes, even in a rich culture medium and with feeder cells (Bennett and Medrano, 2002; Sviderskaya et al, 2003). Two human melanocyte strains lacking functional p16 both showed a greatly extended lifespan, p53-dependent senescence, and immortalisation by hTERT alone (Sviderskaya et al, 2003).

These findings suggested a parallel with melanocytic lesions. Humans carrying p16 mutations have not only increased susceptibility to melanoma, but usually also numerous melanocytic naevi (moles), often large (Gruis et al, 1995; Bennett and Medrano, 2002; Bennett, 2003), implying a role for p16 in limiting naevus growth in these families. This led to surmises that moles may be melanocyte clones that have proliferated following a first mutation, then senesced (Bennett and Medrano, 2002; Mooi and Peeper, 2002; Bastian, 2003). Reports of activating BRAF mutations in most melanomas (Davies et al, 2002) and around $80 \%$ of naevi (Pollock et al, 2003) provided a likely candidate for the mutation that most commonly initiates proliferation. BRAF is a protein serine/ threonine kinase that transduces mitogenic and other signals from RAS to MAPK (Robinson and Cobb, 1997) and can regulate cell proliferation. The most common oncogenic BRAF mutation in melanomas, V600E (formerly called V599E), results in constitutive ERK signalling in vivo and can transform immortal fibroblasts (Davies et al, 2002) and immortal mouse melanocytes (Wellbrock et al, 2004).

The senescence studies also suggested mechanisms for progression to melanoma. Malignant melanomas can originate in naevi, sometimes through intermediate lesions (Clark et al, 1984; Herlyn et al, 1985; Mooi, 1997; Hussein and Wood, 2002), as follows. Dysplastic naevi tend to be large, with architectural irregularities but not progressive growth, unlike melanoma (Mooi, 1997). Radial growth phase (RGP) melanomas are thin, growing only in or near the epidermis, while vertical growth phase (VGP) melanomas invade more deeply and are competent for metastasis and immortal in cell culture (Clark et al, 1984; Herlyn et al, 1985; Clark, 1991). We proposed a genetic model, in which benign and dysplastic naevi represent p16 and p53-dependent senescence, while melanomas arise by immortalisation of melanocytes (Bennett, 2003; Sviderskaya et al, 2003; Bennett, 2006). Published biological and molecular data (Talve et al, 1997; Keller-Melchior et al, 1998; Glaessl et al, 1999; Rudolph et al, 2000; Hussein and Wood, 2002; Bennett, 2003; Sviderskaya et al, 2003) were consistent with this model, but not conclusive, although a convincing report of cell senescence in melanocytic naevi has appeared recently (Michaloglou et al, 2005). We have now identified the genetic requirements for immortalisation of human melanocytes, and systematically studied molecular markers and mediators of cell senescence in clinical pigmented lesions of increasing malignancy. The results confirm that normal melanocyte senescence in culture is p16-dependent, show that the senescence in benign pigmented naevi is not p53-dependent but involves p16 expression, and support a key role for cell senescence in melanoma suppression. We also confirm and extend another finding of Michaloglou et al (2005) on senescence-like inhibition of normal melanocyte growth by exogenous ${ }^{V 600 E} \mathrm{BRAF}$. This inhibition correlates with upregulation of p16, but not $\mathrm{p} 21$.

\section{MATERIALS AND METHODS}

\section{Melanocyte culture and gene transfer}

Primary human melanocyte strains Nohm1 (Bennett et al, 1985), 830c (Scott et al, 2002) and HM303CN (Minwalla et al, 2001) were grown as described (Bennett et al, 1985), except in the following melanocyte medium (Sviderskaya et al, 2003): RPMI 1640 medium, $10 \%$ foetal calf serum, $200 \mathrm{nM}$ 12-O-tetradecanoyl phorbol 13-acetate (Sigma Chemical Co., Poole, UK), $200 \mathrm{pm}$ cholera toxin (Sigma), $10 \mathrm{ng} \mathrm{ml}^{-1}$ human stem cell factor (R\&D Systems, Abingdon, UK) and $10 \mathrm{~nm}$ endothelin 1 (Sigma), gassed with $10 \% \mathrm{CO}_{2}$. Supplements shortly after retroviral infection also included $1 \mu \mathrm{M}$ insulin, $40 \mathrm{pM}$ fibroblast growth factor 2 (R\&D Systems, Abingdon, UK) and $1 \mu \mathrm{g} \mathrm{ml}^{-1} \alpha$-tocopherol. Melanocytes for the BRAF studies only were obtained from Cascade Biologics and were grown in medium 254 with HMGS supplements (Cascade Biologics, Mansfield, UK). WM266.4 melanoma cells (ATCC), all producer cells and HeLa cells were grown in DMEM with $10 \%$ calf serum. Retroviral gene transfer into melanocytes was largely as described (Sviderskaya et al, 2003). All vectors, with or without inserts, were from Dr CJ Jones (Pathology, University of Wales College of Medicine, Cardiff, UK); the HPV16-E7 vector was originally from D Galloway (Fred Hutchinson Cancer Research Center, Seattle, WA, USA). pBABEpuro or pBABEneo vectors were transfected into the Omega $\mathrm{E}$ ecotropic packaging line, and supernatant containing virus used to infect $\varphi$ CRIP amphotropic packaging cells (Danos and Mulligan, 1988). LXSN vectors were grown in PA317 amphotropic packaging cells (Halbert et al, 1991). $\varphi$ CRIP or PA317 medium containing infectious virus was harvested (using appropriate containment procedures) and frozen. Melanocytes were infected 1 day after plating them at $4-5 \times 104 \mathrm{ml}^{-1}$. Supernatant was thawed, filtered $(0.45 \mu \mathrm{m})$, supplemented with polybrene $\left(3.5 \mu \mathrm{g} \mathrm{ml}^{-1}\right)$, and incubated overnight with melanocytes. Conditioned medium from the melanocytes before infection was then replaced. Normal culture was resumed after 2-3 days. For infection with a second vector, the procedure was repeated 2 weeks later. Inserts included hTERT cDNA (Geron Corp., Menlo Park, CA, USA) in pBABEpuro and HPV16-E7 in LXSN, as described before (Halbert et al, 1991; Sviderskaya et al, 2003). The p16 antisense vector contained p16 exon $1 \alpha$ cloned in the antisense orientation between the BamH1 and EcoR1 sites of pBABEneo and expressed from the viral LTR. Normal human CDK4 cDNA was likewise expressed from the viral LTR of pBABEneo. Some melanocyte cultures following infection were plated on XB2 keratinocyte feeder cells $\left(3 \times 10^{4} \mathrm{ml}^{-1}\right)$ (Sviderskaya et al, 2003).

Transient transfection was by Nucleofector ${ }^{\mathrm{TM}}$ technology, using the manufacturer's protocols (Amaxa GmbH, Cologne, Germany). $5 \times 10^{5}$ melanocytes were transfected with $5 \mu \mathrm{g}$ DNA of Myc-tagged pEFm vector containing either no insert, wild-type or human ${ }^{6600} B R A F$ sequences, and cultured in $1 \mathrm{ml}$ normal medium in a well of a six-well plate for 5 days before assays. 


\section{Growth curves and calculation of population doublings}

Two near-confluent cultures were each counted in triplicate by haemocytometer, pooled and replated at a recorded density. The relative population increase during that passage was calculated and converted to population doublings.

\section{Immunoblotting}

Cells were washed twice in PBS, covered in RIPA lysis buffer (Sviderskaya et al, 2003) and scraped off the plates. Protein concentration was quantified using the bicinchoninic acid (BCA) method. Protein $(30 \mu \mathrm{g})$ were electrophoresed through a $12 \%$ SDS - polyacrylamide gel and transferred to PVDF membranes by semi-dry blotting. Immunodetection was by enhanced chemiluminescence (Amersham, Little Chalfont, UK). Antibodies used were mouse anti-p16 (Novocastra, Newcastle, UK, or from NeoMarkers, Newmarket, UK for the BRAF work); rabbit anti-Myc (Abcam, Cambridge, UK), rabbit anti-p21 and rabbit anti-ERK (Santa Cruz/ Autogen Bioclear, Mile Elm, UK), and mouse anti-phospho-ERK (Sigma). Second antibodies were appropriate HRP-conjugated anti-mouse or rabbit Igs (Stratech, Soham, UK).

\section{Immunostaining of lesion sections}

Formalin-fixed, paraffin-embedded clinical specimens were obtained from St George's Hospital with approval from the local Research Ethics Committee. JC or HC performed histopathological diagnosis. Adjacent, parallel sections from the same lesions were used for direct positional comparisons of staining for p16, Mart1, p53, p21 and CHK2. 4- $\mu$ m sections were mounted on poly-L-lysinecoated slides. Sections were deparaffinised, rehydrated in Histoclear and placed in deionised water for at least $30 \mathrm{~s}$. Target retrieval was by microwave heating with $0.01 \mathrm{~m}$ citrate buffer, $\mathrm{pH}$ 6.0. Slides were rinsed with $50 \mathrm{~mm}$ TBS wash buffer with $0.3 \mathrm{M} \mathrm{NaCl}$ and $0.1 \%$ Tween. Immunohistochemistry used the EnVision Fast Red system with alkaline phosphatase (DakoCytomation, Ely, UK). Antibodies were at recommended dilutions. Anti-p16, p53 and MART-1 antibodies were from Novocastra, anti-CHK2 from Autogen Bioclear, and anti-p21 from BD Pharmingen, Oxford, UK. Several types of lesions including positive and negative control sections were always immunostained simultaneously.

\section{Immunostaining of cultured cells}

Normal human neonatal epidermal melanocytes (Cascade Biologics, Mansfield, UK) and control cell lines were grown on glass coverslips. Cultures were fixed with fresh $3.7 \%$ formaldehyde in PBS. Permeabilisation was in $0.5 \%$ Triton $\mathrm{X}-100$ in PBS. Nonspecific sites were blocked in $1 \%$ bovine serum albumin in PBS. The cells were exposed to anti-p16 (NeoMarkers), anti-Myc tag (Abcam), or anti-Ki67 (Abcam) primary antibodies followed by either anti-mouse $\mathrm{Cy} 3$ or anti-rabbit $\mathrm{Cy} 2$ secondary antibodies (Jackson ImmunoResearch Laboratories). Cells were counterstained with DAPI and mounted in DABCO (Sigma).

\section{Detection of acidic $\beta$-galactosidase (Dimri et al, 1995)}

Frozen sections of benign congenital naevi of minimal diameter $10 \mathrm{~mm}$ were used. Biopsy specimens were mounted in OCT embedding compound and rapidly frozen in isopentane. Frozen sections were mounted on poly-lysine-coated slides, thawed, fixed ( $1 \mathrm{~min}$ ) in $1 \%$ formaldehyde in PBS, and washed twice in PBS. They were immersed in staining solution $(10 \%$ PBS, $3.95 \mathrm{M}$ $\mathrm{K}_{3} \mathrm{Fe}(\mathrm{CN})_{6}, 5 \mathrm{M} \mathrm{K}_{4} \mathrm{Fe}(\mathrm{CN})_{6}, 1 \mathrm{M} \mathrm{MgCl}_{2}, 1 \mathrm{mg} \mathrm{ml}^{-1} \mathrm{X}$-gal, pH 6.0) for $24 \mathrm{~h}$ at $37^{\circ} \mathrm{C}$. Sections were rinsed, counterstained with eosin $\mathrm{Y}$, rinsed, dehydrated, cleared and mounted. Senescent cultured melanocytes gave a positive control.
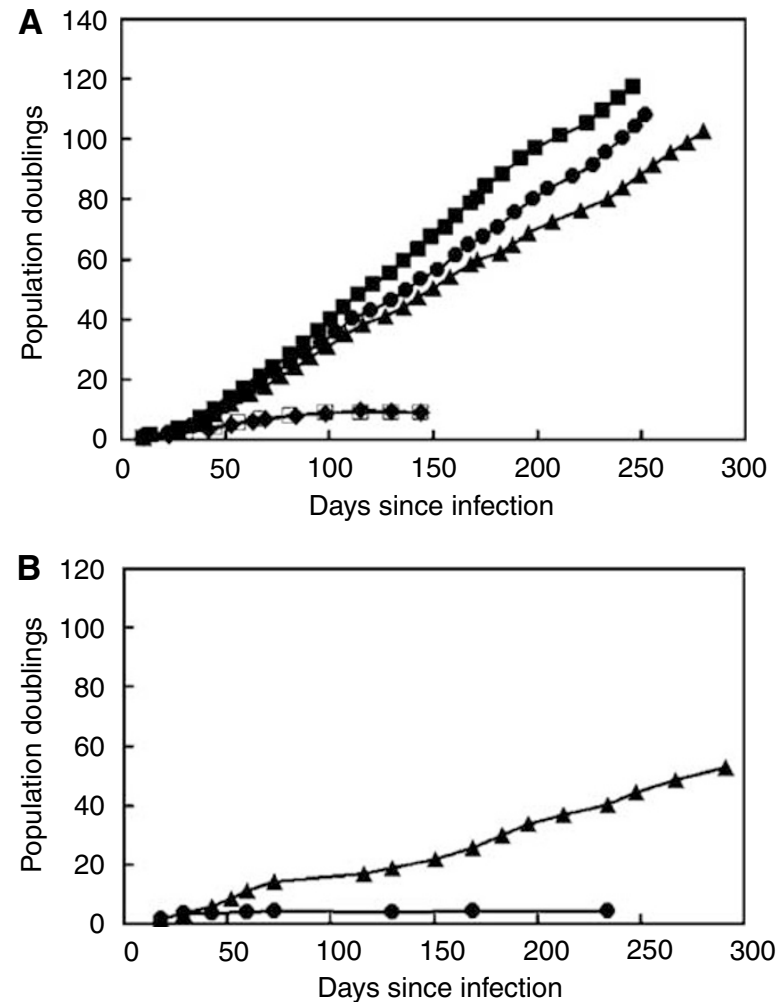

C

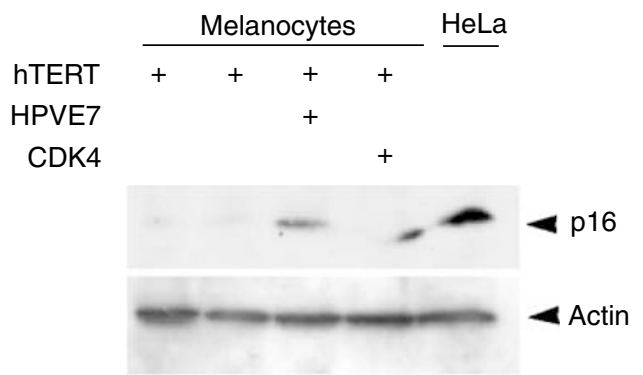

Figure I Genetic requirements for immortalisation of normal human melanocytes. (A) Growth of a representative human melanocyte strain (830c) following transduction of the indicated experimental or control sequences with pBABE amphotropic retroviruses. hTERT was added two weeks before the other sequences. Time since the second infection is shown. Immortalisation was seen following infection with hTERT in combination with each of the other experimental sequences. ( 1 ) HPVI6-

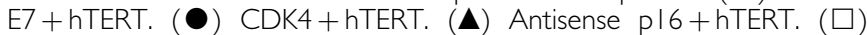
pBABEpuro + pBABEneo. ( ) pBABEpuro + pBABEpuro. Two other human melanocyte strains, Nohm-I (Bennett et al, 1985) and HM303CN gave similar results (not shown). The resulting immortal melanocyte lines were generically called Hermes 3 (from Nohm-I), Hermes 4 (from 830c) and Hermes 5 (from HM303CN) (see (Sviderskaya et al, 2003) for Hermes I and 2). Growth was monitored until cells either stopped growing or achieved at least twice the number of population doublings for that cell strain's normal lifespan (full curve not necessarily shown), when they were deemed immortal. (B) Growth of 830c melanocytes following infection with hTERT only. In 2/6 cases (one shown here), immortalisation was seen after a lag, with hTERT only. (A) hTERT; (O) pBABEpuro. (C) Immunoblot analysis for pl6, showing negligible pl6 expression in the two normal melanocyte cultures that immortalised with hTERT only. First lane: HM303CN melanocytes with hTERT. Second lane: 830c melanocytes with hTERT. 3rd and 4th lanes: Nohm-I melanocytes with hTERT and with HPVI6-E7 or CDK4 as indicated. HeLa: HeLa cells as positive control for pl 6 expression. 


\section{RESULTS}

\section{Immortalisation of normal human melanocytes}

We previously reported that p16-deficient but not normal human melanocytes could be immortalised by retrovirally mediated expression of hTERT (Sviderskaya et al, 2003), suggesting that RB1-pathway deficiency and hTERT expression were sufficient for melanocyte immortalisation. However, this evidence was weakened by the possibility that other genetic aberrations might be present in the two p16-deficient melanocyte strains used (Sviderskaya et al, 2003), as these were from familial melanoma patients. We have now tested the immortalisation requirements of three normal human melanocyte strains. We used the following exogenous genes to disrupt p16/RB1 signalling: an antisense p16 sequence, CDK4 cDNA overexpressed from a viral promoter, and the E7 oncogene of human papillomavirus 16 (HPV16-E7). Melanocytes were infected with amphotropic retroviruses containing hTERT or no insert, and separately infected with an RB1-disrupting vector or a control vector. Some infected cultures were initially grown with keratinocyte feeder cells.

We previously reported that normal melanocytes could not be immortalised using hTERT alone, even in the presence of feeder cells (Sviderskaya et al, 2003). However, as shown in Figure 1A, hTERT in combination with any of three approaches to disrupt the p16/RB1 pathway could immortalise normal melanocytes. Similar results were obtained with all three independent normal melanocyte strains. Cytogenetic analysis showed initially normal diploid karyotypes for most of the immortalised cultures. Immunoblotting of cultures infected with antisense p16 and sense CDK4 confirmed repression of p16 expression and increased CDK4 expression, respectively (data not shown). hTERT alone once again gave no immortalisation in 4/6 experiments, including two cultures grown with feeder cells. Slowly growing immortal cells were obtained in $2 / 6$ experiments, but in both cases progressive growth started only after a growth plateau and long lag of several months (Figure 1B), compared to immediate growth in the presence of CDK4, antisense p16 or HPV16-E7 as well as hTERT (Figure 1A). Moreover, immunoblot analysis (Figure $1 \mathrm{C}$ ) revealed virtually no p16 in

Figure 2 Typical expression of senescence-associated proteins in benign compound naevi and normal epidermis. Immunostained proteins appear red and nuclei blue (haematoxylin counterstain, except where noted). Acidic $\beta$-galactosidase gives a blue colour, with eosin (pink) counterstain. (A) Top and second rows, detection of melanocytic marker MARTI to show melanocytes and for $\mathrm{p} / 6$ in parallel sections of the same biopsy. Top panels, low magnification of compound naevus $(\mathrm{N})$, showing intense pl6 immunostain (without haematoxylin). E, epidermis. Scale bar, $200 \mu \mathrm{m}$. Second row, higher magnification of another naevus to show detail. Contrast slightly enhanced in right image to clarify chromatin detail. Scale bar, $20 \mu \mathrm{m}$. Levels of p 16 expression vary, with some cells not visibly positive. Immunostain where present is both nuclear and cytoplasmic. Arrows: large multinucleate cells; arrowheads: large nucleoli. Third row, parallel sections of same naevus as top panels, immunostained for $\mathrm{p} 53$ and p21 as indicated. No p53 or p21 was detected. Brown material (arrowheads) is melanin pigment. Bottom row, high magnification of haematoxylin-stained areas of a benign compound naevus (left), showing heterochromatic foci in nuclei (arrows), and of a VGP melanoma (right) showing absence of such foci. Note that lesions are heterogeneous and not all areas showed such clear differences. Contrast digitally enhanced as sections were lightly stained. Scale bar, $20 \mu \mathrm{m}$. (B) Top, normal adjacent epidermis from same sections as (A) top. Scale bar, $50 \mu \mathrm{m}$. MARTI (left) shows distribution of normal melanocytes (arrows), which have no detectable pl6 (right). Middle and bottom, MARTI and acidic $\beta$ galactosidase in parallel sections of a benign congenital naevus. All cells of naevus $(N)$ show both markers. Higher magnification (bottom) shows some acidic $\beta$-galactosidase reactivity in whole basal epidermis (arrowheads), but faint compared to naevus cells. Note: frozen sections were needed for this stain, and were available only for congenital naevi. Arrows, melanocytes. Scale bars, I50 $\mu \mathrm{m}$ (middle), $50 \mu \mathrm{m}$ (bottom).

either of the two cultures that immortalised with hTERT alone. p16 is normally expressed by high-passage human melanocytes (Bandyopadhyay et al, 2001; Bennett and Medrano, 2002), and

A
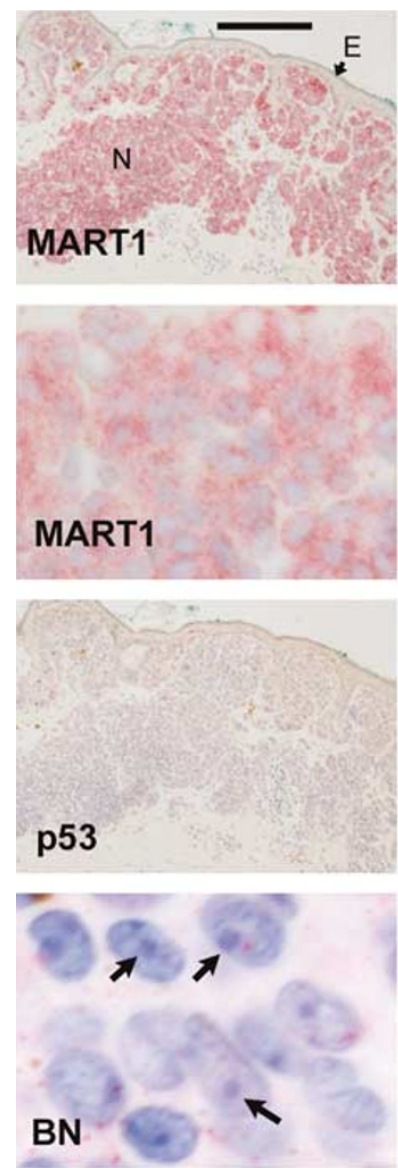

B

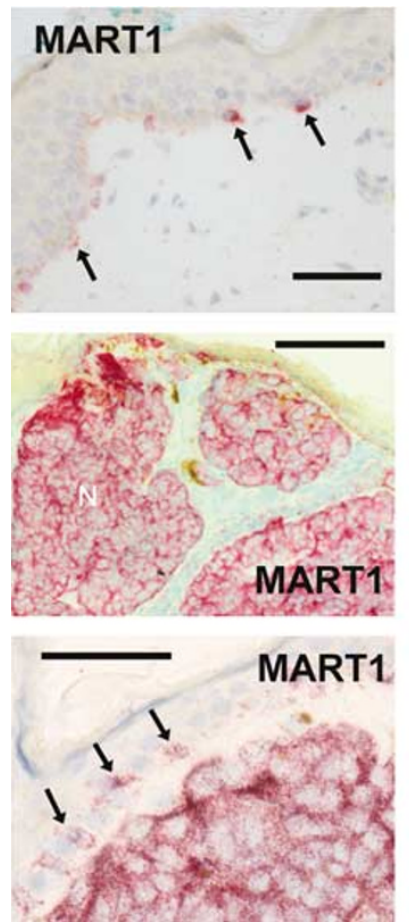

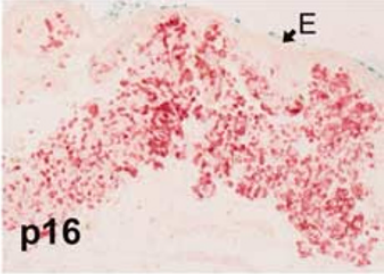
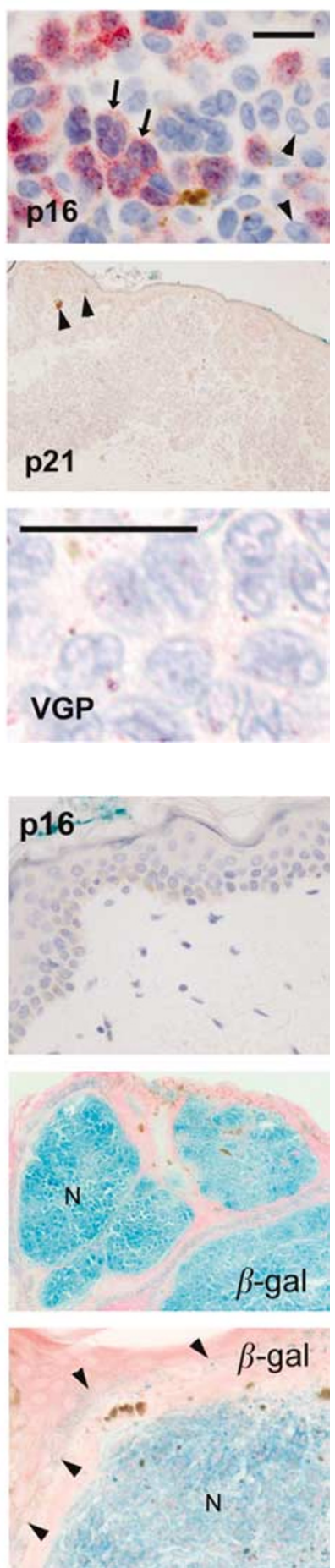
has thus been silenced in the cells that eventually grew in these two cultures, probably (given the long lag before growth) from a small number of variant cells. In comparison, the cells infected with HPV16-E7 and with overexpressed CDK4, where the entire culture grew immediately, did not lose p16 protein (Figure 1C). This is as expected, since these two proteins directly inhibit the p16/RB pathway, so there would be no selection for cells lacking p16. In summary, in $6 / 6$ cases, hTERT expression failed to immortalise normal melanocytes without $\mathrm{p} 16 / \mathrm{RB}$ pathway disruption, whereas with each of three gene combinations expressed in three melanocyte strains, p16/RB pathway disruption combined with hTERT did immortalise melanocytes efficiently and with no lag.

\section{Evidence of p16-dependent senescence in benign naevi}

We now used immunostaining to test expression of markers and mediators of p16- and p53-dependent senescence in sections of benign and malignant melanocytic lesions. p16 was clearly detectable in $100 \%$ of benign compound naevi examined (Figure 2A, Table 1). Typically, staining was found throughout the lesion, although at the single-cell level, lesions were patchworks of immunostained and unstained naevus cells (Figure 2A). As illustrated, there was no detectable variation of p16 immunostaining with depth in these lesions. p16 was nearly always nuclear as well as cytoplasmic in naevi; nuclei stained with Fast Red as well as haematoxylin appear purple rather than blue (Figure 2A). Naevus cells often appeared large and sometimes multinucleate (Figure 2A), properties seen in senescent melanocytes (Bennett and Medrano, 2002). Prominent heterochromatic foci were often visible in the nuclei (Figure 2A, lower left), reminiscent of the heterochromatic foci described in senescent cells in culture (Narita et al, 2003). These foci appeared to be uncommon in melanomas, as illustrated for a VGP lesion (Figure 2A, lower right), although such morphological features are variable and difficult to quantitate. Importantly, no p16 was detected in normal epidermal melanocytes (Figure $2 \mathrm{~B}$ ). The region illustrated is typical of normal epidermis (well separated from the lesion), which we examined in all specimens where it was present, totalling at least several hundred melanocytes. No p16 immunostaining was found. Naevi were then stained for acidic $\beta$-galactosidase activity, or 'senescence-associated $\beta$-galactosidase' (Dimri et al, 1995; Sharpless and DePinho, 2004). This appears to be expressed reliably by senescent cells, although also by some other cells, including human cultured melanocytes (Dimri et al, 1995). It appears to be lysosomal $\beta$-galactosidase (Kurz et al, 2000). (This marker was studied only in large congenital naevi, since fresh, frozen sections were required and acquired naevi were too small for material to be spared from routine diagnosis for freezing.) We observed strong to moderate acidic $\beta$-galactosidase activity in $7 / 7$ benign congenital naevi
(Figure 2B). In comparison, there was no specific staining of normal epidermal melanocytes (Figure $2 \mathrm{~B}$ ).

Benign naevus cells thus did appear senescent, from two molecular markers and several biological and morphological properties (also including growth stasis). To address what type of senescence had occurred, naevi were immunostained for p53 and p21. p21 should be expressed in p53- but not p16-dependent senescence, while p53 levels are likely to be detectable in cells undergoing p53-dependent senescence (Sviderskaya et al, 2003). p21 was not detected in any of nine benign naevi, and only $1 / 7$ showed traces of p53 (Table 1; Figure 2A). Thus the senescence in benign melanocytic naevi is not of the p53-dependent type, and so is either p16-dependent or some novel form of senescence.

\section{Evidence for escape from p16-dependent senescence in dysplastic naevi}

Dysplastic naevi also all expressed some p16, although reactivity was more patchy (Figure $3 \mathrm{~A}$ ) and half were predominantly negative (Table 1). Interestingly, p16 was detected only in the cytoplasm in some areas of these lesions (Figure 3A), whereas it generally appeared both nuclear and cytoplasmic in benign naevi (Figure 2A). Cytoplasmic p16 may sometimes be nonfunctional (see Discussion). In culture, p16 deficiency can lead to prolonged cell proliferation and $\mathrm{p} 53$-dependent senescence, as in cultured p16-deficient melanocytes (Sviderskaya et al, 2003). A proportion of dysplastic naevi did indeed show pockets of p53-positive cells, sometimes with detectable p21 (Table 1; Figure 3A). p53 location was nuclear or nuclear and cytoplasmic. Typically, however, neither protein was observed in most of the lesion.

\section{An atypical naevus from a p16-deficient patient: high p16 expression and possible p53-dependent senescence}

Naevi from patients with biallelic p16 mutations tend to be large. We surmised that these might exhibit p53-dependent senescence, as confirmed for cultured melanocytes from these patients (Sviderskaya et al, 2003). We analysed an atypical naevus from one of the same two patients with biallelic point mutations in p16 (Huot et al, 2002) (Figure 3B). The mutant p16 was strongly expressed in nearly all lesional cells, and not in normal adjacent skin. This p16 protein was mostly cytoplasmic, however (Figure 3B), consistent with its known dysfunctionality in this patient (Huot et al, 2002). p21 and p53 were indeed expressed widely in this naevus, generally together, although less ubiquitously than p16 (Figure 3B). Pigmented melanophages (macrophages that have ingested melanin) and lymphocytes were often found near dermal p53-positive cells (Figure 3B), suggestive of melanocyte death (see Discussion).

Table I Differential expression of p16, p53, p2I and CHK2 in pigmented lesions of increasing malignancy

\begin{tabular}{|c|c|c|c|c|c|c|c|c|c|c|c|c|}
\hline \multirow[b]{3}{*}{ Lesion type } & \multicolumn{12}{|c|}{ Proportion of lesions positive } \\
\hline & \multicolumn{3}{|c|}{ pl6 } & \multicolumn{3}{|c|}{ p53 } & \multicolumn{3}{|c|}{ p2I } & \multicolumn{3}{|c|}{ CHK2 } \\
\hline & $++^{a}$ & $+^{a}$ & $A I^{\mathrm{a}}$ & ++ & + & All & ++ & + & All & ++ & + & All \\
\hline Benign compound naevi & $10 / 11$ & $|/| \mid$ & ||$/||$ & $0 / 7$ & $1 / 7$ & $1 / 7$ & $0 / 9$ & $0 / 9$ & $0 / 9$ & $0 / 8$ & $6 / 8$ & $6 / 8$ \\
\hline Dysplastic naevi & $5 / 9^{b}$ & $4 / 9$ & $9 / 9$ & $0 / 7$ & $4 / 7$ & $4 / 7$ & $0 / 7$ & $2 / 7$ & $2 / 7$ & $1 / 6$ & $3 / 6$ & $4 / 6$ \\
\hline RGP melanomas & $7 / 14^{b}$ & $7 / 14$ & $14 / 14$ & $0 / 8$ & $6 / 8$ & $6 / 8$ & $0 / 6$ & $6 / 6$ & $6 / 6$ & $2 / 7^{c}$ & $5 / 7^{c}$ & $7 / 7^{c}$ \\
\hline VGP melanomas & $3 / 14^{b, d}$ & $11 / 14$ & $14 / 14$ & $1 / 8$ & $7 / 8$ & $8 / 8$ & $0 / 8$ & $4 / 8$ & $4 / 8$ & $0 / 8$ & $6 / 8^{c}$ & $6 / 8^{c}$ \\
\hline
\end{tabular}

${ }^{a}++$ : fraction of lesions that were predominantly positive (i.e. with $51-100 \%$ of cells immunostained), out of number of lesions assessed. + : fraction of lesions with detectable immunostaining up to $50 \%$ of cells). All: all positive lesions, sum of + and ++ . Lesions were scored $(0,+,++)$ by two independent observers, who agreed on the scores. ${ }^{\text {b Some }}$ cytoplasmic-only reaction. Reaction generally appeared fainter in melanomas than in naevi. 'Some lesions with intensely positive areas. ${ }^{\mathrm{C}} \mathrm{VGP}$ melanomas that were predominantly pl6-positive were all relatively small. Columns in bold show a trend between lesion types $\left(P<0.01, P<0.02, P<0.005\right.$, respectively, for $p \mid 6$, p53 and $\mathrm{p} 2 \mathrm{I}$, by the $\chi^{2}$ test) 


\section{Further loss of p16 and p21 expression with melanoma} progression

In all primary melanomas examined, we detected neither immunoreactive p21 nor p53 in most cells, although most lesions had a few areas with positive cells (Table 1). Likewise, in many RGP and nearly all VGP melanomas, most areas lacked detectable p16 (Table 1). Even where present, p16 immunoreactivity was generally noticeably fainter and more often cytoplasmic than in naevi (Figure 4A and B). In RGP melanomas, p53 and p21 were often colocalised with each other, with pigmented melanocytic cells, and with p16 (Figure 4A). Melanophages and/or lymphocytes

\section{A}

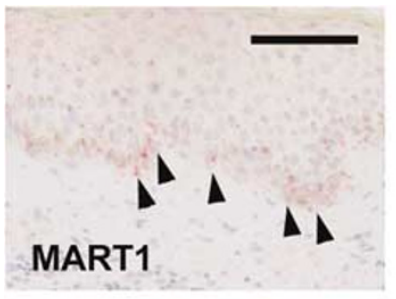

p53

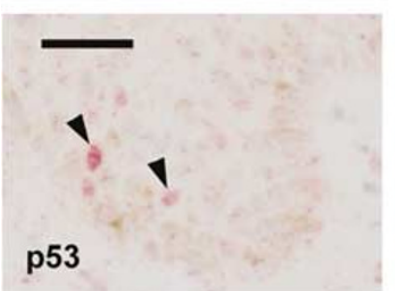

B
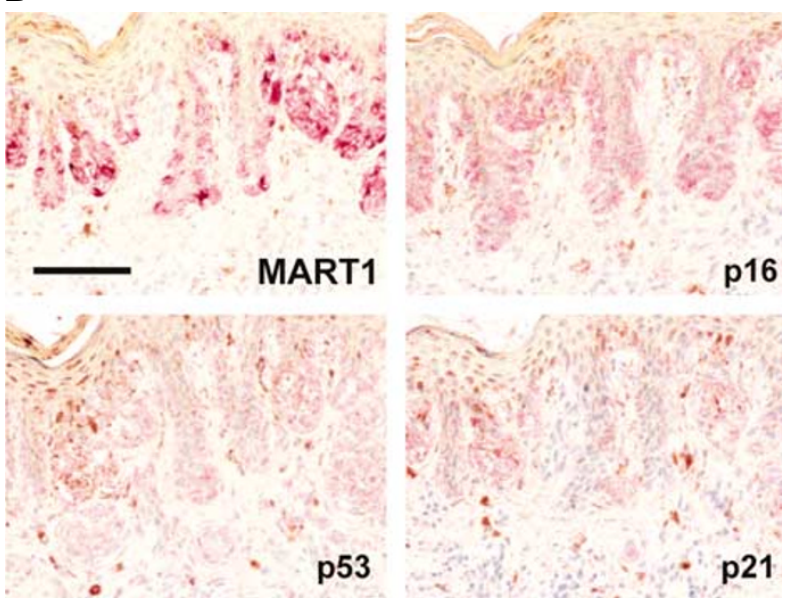

p16
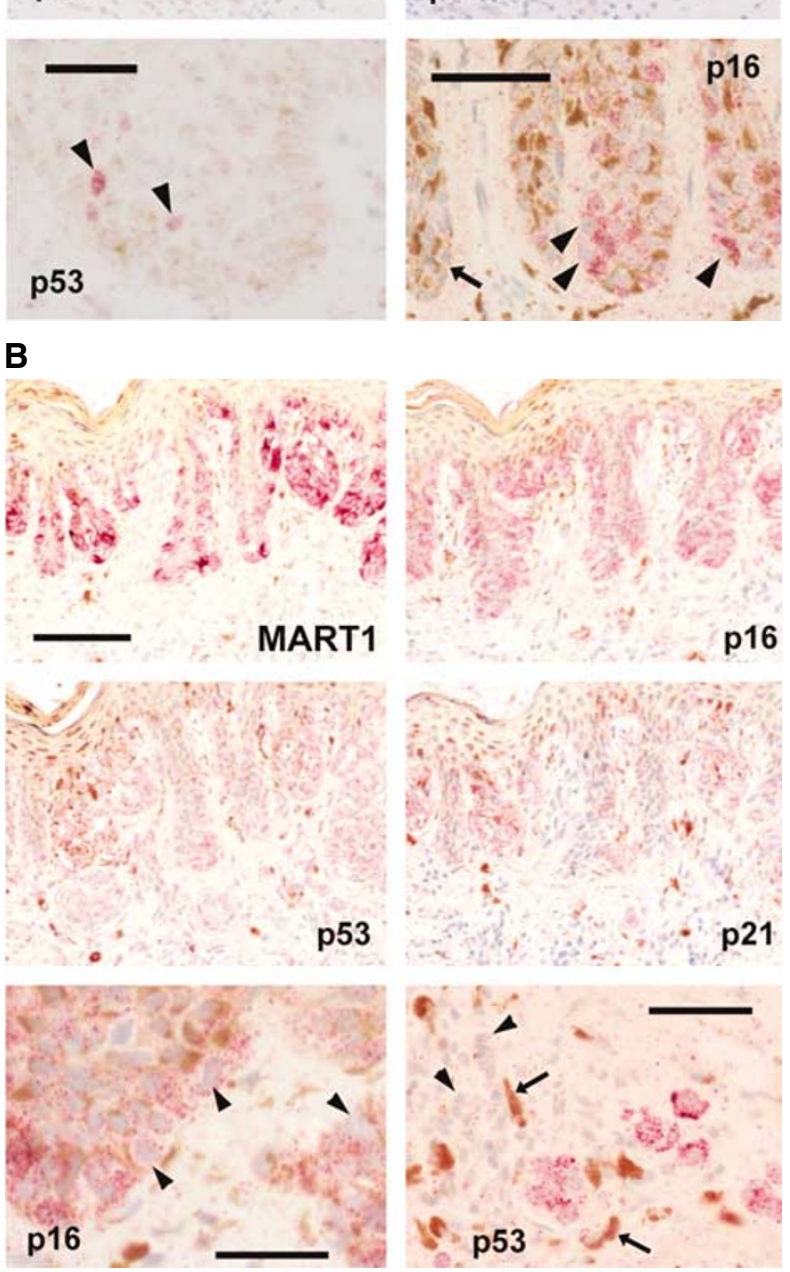

were again often found nearby (Figure $4 \mathrm{~A}$ ). The immunostained cells were often large and sometimes multinucleate (Figure 4A), features of senescent cells as already mentioned. VGP melanomas showed similar colocalisation of the markers studied, typically at the edges of the lesion, with the bulk of the nodule negative. Even in these few positive areas in VGP melanomas, both p16 and p53 tended to be cytoplasmic in location (Figure 4B). In the area shown, some lesional cells were well pigmented and also had prominent heterochromatic foci (Figure 4B).

\section{Differential CHK2 expression in pigmented lesions}

Checkpoint kinase $\mathrm{CHK} 2$ is activated and mediates p53 activation on DNA damage and in p53-dependent senescence (d'Adda di Fagagna et al, 2003; Von Zglinicki et al, 2005). As some activated proteins become stabilised, we surmised that CHK2 levels might change with melanoma progression. Immunostaining for $\mathrm{CHK} 2$ partially supported this idea. Most lesions in each category showed some CHK2 reaction, although generally most of each lesion was negative, as with p53 (Figure 4C; Table 1). Intense reaction was observed only in melanomas (Figure 4C; Table 1). CHK2 immunoreactivity was generally present in areas with p53 reactivity (Figure 4C, compare with Figures $2-4 \mathrm{~A}$ ). The naevus from the p16-deficient patient was positive for CHK2 (not shown).

\section{Growth inhibition and p16 elevation by oncogenic BRAF in cultured melanocytes}

We and others had speculated that senescence in moles might arise following proliferation due to mitogenic mutations, especially the common ${ }^{1600 E} B R A F$ mutation. Accelerated senescence induced by oncogenes has been reported in other normal human cell types. To investigate this potential mechanism, we tested whether $B R A F$ sequences could induce a response resembling accelerated senescence in normal human melanocytes. Cells were transfected with ${ }^{W T} B R A F$ (wild-type) or ${ }^{V 600 E} B R A F$ sequences or a control vector. The Nucleofection procedure gave efficient transfection (typically around $30-40 \%$ with $B R A F$ sequences), and effects were assessed on the whole, unselected cultures after 5-10 days. Findings were reproduced in four independent experiments, and typical results are shown in Figure 5. As shown in Figure 5A, expression of the BRAF sequences could readily be detected. Elevation of MAPK signalling, indicated by ERK phosphorylation relative to ERK abundance, was strong with ${ }^{V 600 E} B R A F(\mathrm{VE})$, but not visible with ${ }^{W T} B R A F$ (WT). Cell proliferation (Ki67 labelling) was significantly reduced in melanocytes transfected with ${ }^{V 600 E} B$ $R A F$ but not ${ }^{W T} B R A F$ (Figure $5 \mathrm{~B}$ ). Note that there was no selection for transfected cells, so the maximum expected growth inhibition is $30-40 \%$ (transfection efficiency). Interestingly, expression of p16 was significantly elevated in cultures transfected with

Figure 3 Immunostaining of senescence effectors in dysplastic naevi. (A) lesions from normal patients. Top and middle, MARTI shows naevus cells throughout basal epidermis in this lesion, yet there is little or no p I6, little p53 and no p2I detected in parallel sections. Scale bar, $100 \mu \mathrm{m}$. Bottom left, detail of p53 immunostaining in same lesion showing a few positive nuclei (arrowheads). Scale bar, $50 \mu \mathrm{m}$. Bottom right, detail of p 16 reaction in a different dysplastic naevus. Scale bar, $50 \mu \mathrm{m}$. Most naevus cells here are strongly positive for pl6, yet the reaction appears generally cytoplasmic (arrowheads: unstained nuclei). Arrow: other parts of this naevus had little or no pl6. (B) lesion from a patient lacking active p 6 because of two germline mutations. MARTI and pl6 immunostaining (top) show similar patterns: nearly all naevus cells were prominently positive for pl6. Many naevus cells are also positive for p53 and p2I (middle). Scale bar, $100 \mu \mathrm{m}$. Bottom left: p 16 reaction is cytoplasmic only (arrowheads: unstained nuclei). Scale bar, $30 \mu \mathrm{m}$. Bottom right: p53-positive naevus cells in dermis, in same lesion, surrounded by pigmented macrophages (arrows) and lymphocytes (arrowheads). Scale bar, $50 \mu \mathrm{m}$. 
${ }^{V 600 E} B R A F$ but not ${ }^{W T} B R A F$, especially in individual cells expressing ${ }^{V 600 E}$ BRAF relative to those expressing ${ }^{W T}$ BRAF (Figure $5 \mathrm{~A}-\mathrm{C}$ ), whereas p21 expression was no higher with ${ }^{V 600 E} \mathrm{BRAF}$ than ${ }^{W T}$ BRAF or the empty vector (Figure $5 \mathrm{~A}$ ). Immunostaining showed frequent nuclear expression of p16 in individual cells expressing ${ }^{600 E}$ BRAF but not ${ }^{W T}$ BRAF (Figure 5C). Moreover, further double immunostaining indicated mutual exclusion between nuclear p16 and Ki67 expression among individual cells (data not shown). Thus, the inhibition of melanocyte proliferation by oncogenic but not ${ }^{W T}$ BRAF correlates with increased abundance and nuclear location of p16, but not p21.

\section{DISCUSSION}

We report firstly that hTERT expression and p16/RB deficiency are necessary and sufficient for immortalisation of human

\section{A}
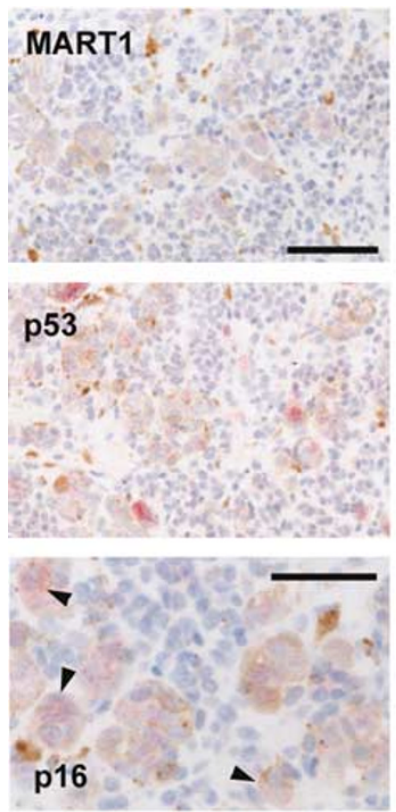

B
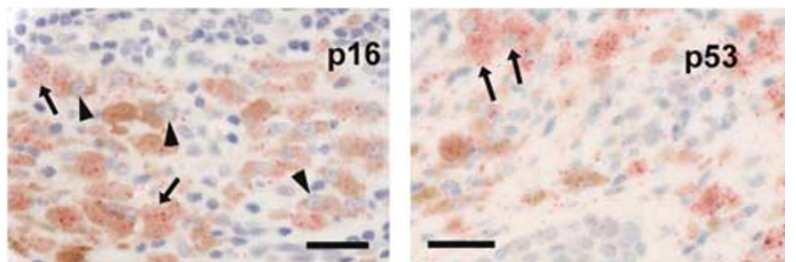

C

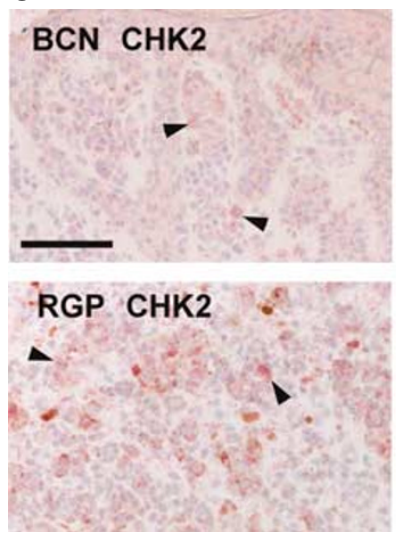

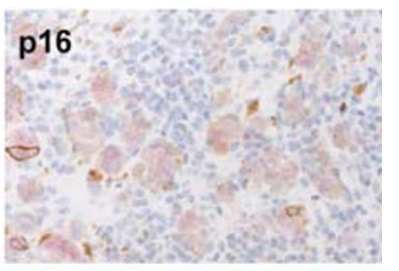
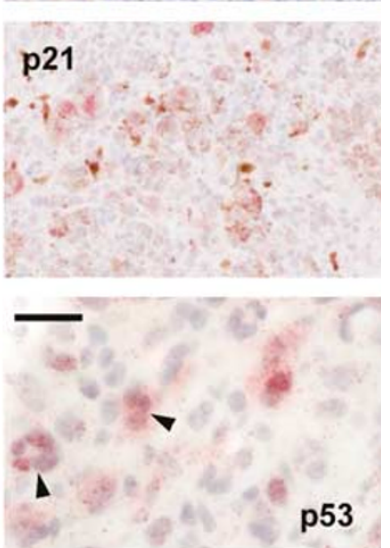

p53
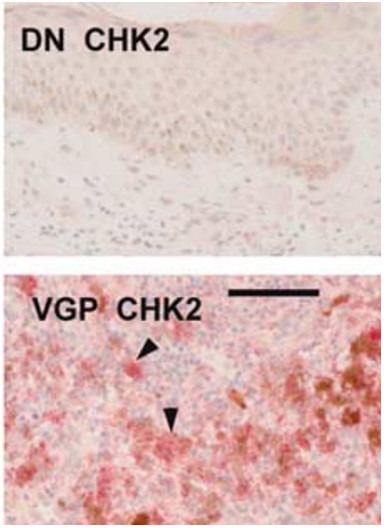

melanocytes. In agreement with the extended lifespans seen in p16-deficient melanocytes (Bennett and Medrano, 2002), this confirms that cell senescence in cultured human melanocytes is normally p16-dependent. Chudnovsky et al (2005) recently described retroviral infection of melanocytes with combinations of genes including mutant CDK4 and hTERT, and reported no short-term alteration in proliferation in vitro, but these were recently explanted, presenescent cultures and were not tested for immortalisation. Melanocytes appear unusual in displaying p16dependent senescence in favourable culture conditions without any apparent stress, unlike p16-dependent senescence in other cell types (Ramirez et al, 2001). One possible residual source of 'stress' is the supraphysiological oxygen concentration (19\%) in $90 \%$ air, but Ramirez et al made no mention of reducing oxygen tension when they abrogated p16-dependent senescence in keratinocytes and mammary cells using feeder cells, and fibroblasts do not need low oxygen to avoid p16-dependent senescence, so a cell-type difference can still be inferred. This provides a possible rationale for the particular relationship between p16 and melanoma, where germline p16 mutations are predominantly associated with familial melanoma (Hayward, 2003; Kefford et al, 2004). Findings from cell culture cannot necessarily be extrapolated to melanocytes in the skin, however, so it was of interest to examine proliferative lesions in vivo directly, for possible parallels.

Cell senescence provides an attractive explanation for the biology of moles, which first grow and then stop growing, often remaining static for decades, as we and others have postulated before (Bennett and Medrano, 2002; Mooi and Peeper, 2002; Bastian, 2003; Bennett, 2003). As proposed before (Bennett, 2003; Bennett, 2006), the initial growth stimulus seems likely to be a mitogenic mutation, usually an activating $B R A F$ or NRAS mutation since these are found in around 80 and $5-15 \%$, respectively, of naevi (Pollock et al, 2003; Gray-Schopfer and Bennett, 2006). Here, we report that all predicted molecular and morphological attributes of cell senescence are found in uncultured benign naevi, including expression of $\mathrm{p} 16$ and acidic $\beta$-galactosidase in all tested lesions, markers also recently reported by Michaloglou et al (2005). Here, we also report the presence of giant cells, multinucleate cells and heterochromatic foci. From previous publications, naevi show very low expression of proliferative marker Ki67 (Healy et al, 1998), and naevus-cell cultures contain large and multinucleate cells and grow poorly (Gilchrest et al, 1986; Halaban et al, 1986) (reviewed Bennett and Medrano (2002)).

Figure 4 Typical immunostaining of senescence mediators in melanomas and naevi. (A) RGP melanomas. Top and middle: The same area of one melanoma is positive for MARTI, pl6, p53 and p2I, showing colocalisation of p16, p53 and p21 in the same area, together with some pigment. Melanophages are also seen. The unreactive cells in this area appear to be melanoma cells; many areas of this tumour were unpigmented and negative for all of these markers. (MARTI can be lost in advanced melanomas). Scale bar, $100 \mu \mathrm{m}$. Bottom left, pl6-positive cells are often large and sometimes have more than one nucleus (arrowheads). Scale bar, $60 \mu \mathrm{m}$. Bottom right: nuclear p53 reaction in another RGP melanoma. Again, some positive cells are multinucleate (arrowheads). Scale bar, $30 \mu \mathrm{m}$. (B) Typical VGP melanoma. Left: rare area of p 16 expression. The positive cells (arrows) are large and well-pigmented (melanin, brown). It is unclear whether all pigmented cells have p|6, but some have prominent nucleoli (arrowheads). Scale bar, $30 \mu \mathrm{m}$. Right: p53 reaction is also rare. Here, the positive cells are again large and colocalised with pigment, and the p53 is cytoplasmic (arrows, cells with clearly negative nuclei). Scale bar, $30 \mu \mathrm{m}$. (C) CHK2 expression in various lesion types. Top left: benign compound naevus. There is nonspecific reaction and occasional stronger reaction (arrowheads). Top right: dysplastic naevus (same area as in Figure 3A, top). Little reaction is visible. Scale bar, $100 \mu \mathrm{m}$. Bottom left: RGP melanoma (same area as in A. top). Prominent CHK2 immunostain (arrowheads) colocalises with p16, p53 and p21. Bottom right, VGP melanoma (same area as in B), showing prominent specific reaction (arrowheads). Some nonspecific reaction is also seen. Scale bar, $100 \mu \mathrm{m}$. 
p16 expression in melanocytic lesions has been studied previously, with results largely consistent with ours (Talve et al, 1997; KellerMelchior et al, 1998). However, the authors did not relate p16 expression to senescence, nor examine other cell-senescence effectors. Expression of p16 in naevi was assumed by these groups to be normal, and was used as a comparison to report downregulation in melanomas. Here however, we find it to be abnormal, since crucially p16 is undetectable in epidermal melanocytes in normal skin, and thus it is overexpressed in naevi. Moreover, p16 expression and growth inhibition could be induced

A

$\begin{array}{ccccc}\text { NHM } & \text { NHM } & \text { NHM } & \text { WM } & \text { HeLa } \\ \text { CONT } & \text { BRAF } & \text { BRAF } & -266 & \\ & \text { WT } & \text { VE } & \end{array}$

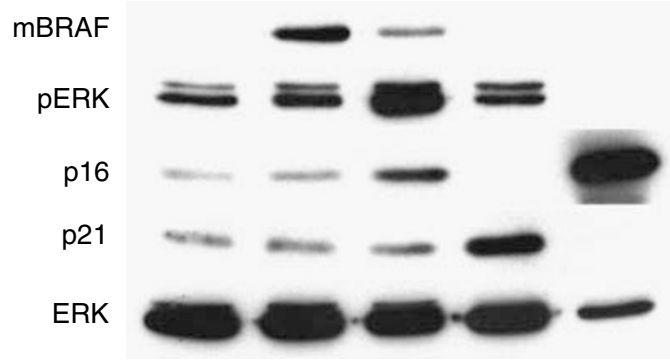

B
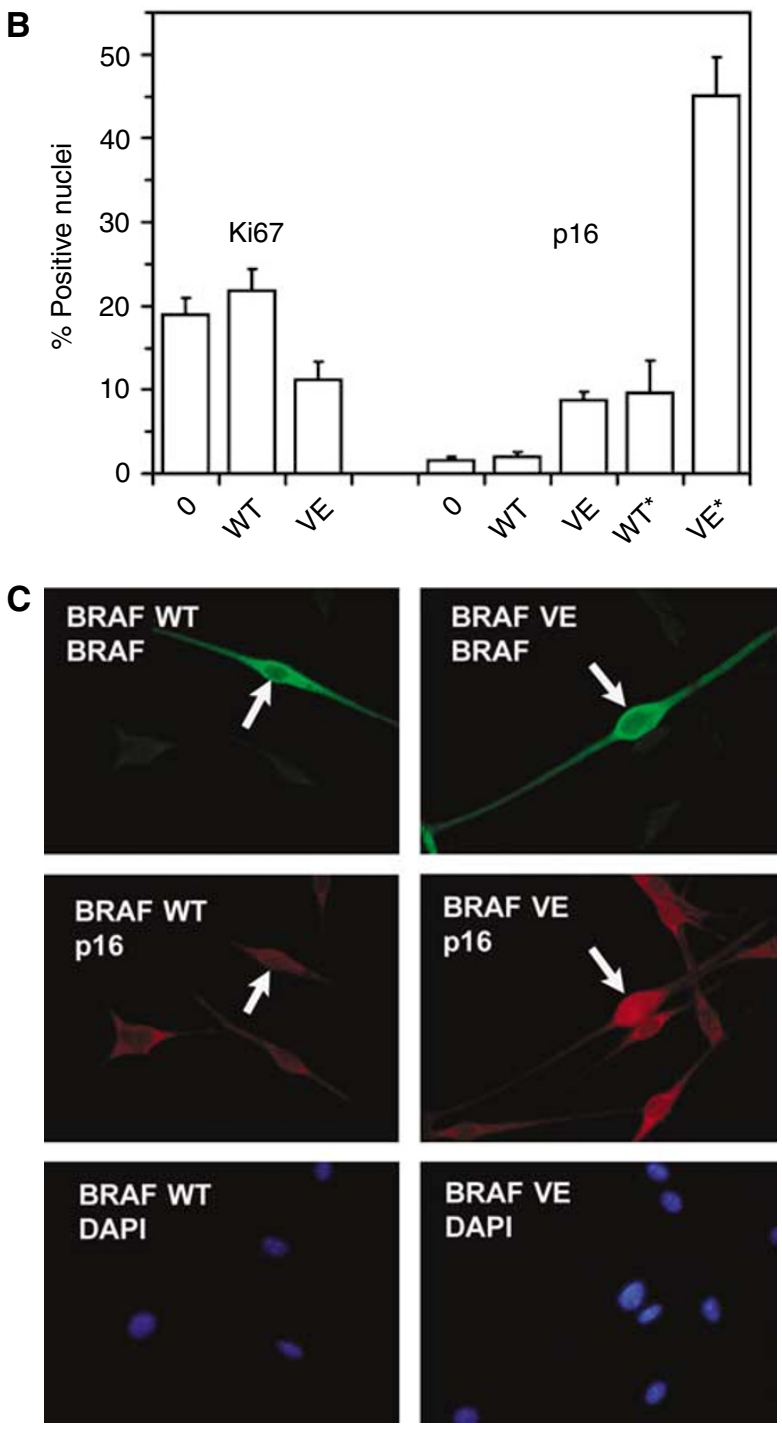

in cultured melanocytes by expression of ${ }^{V 600 E}$ BRAF. This was also recently reported by Michaloglou et al (2005), although without any quantitation of p16. They observed growth arrest and acidic $\beta$ galactosidase in nearly all the cells after 21 days, concluding that the inhibited growth was a form of premature senescence. Here, we additionally report that nuclear translocation of p16 occurred, that ${ }^{W T}$ BRAF expression did not impair growth nor increase p16 expression or nuclear location, and that $\mathrm{p} 21$ expression was not correlated with the growth inhibition. Thus, if this is senescence, it is not effected by the p53-p21 pathway. It may be either p16dependent or a novel form of senescence, with as-yet unknown effector(s) in addition to p16. It seems comparable to the premature senescence reported in other cells in response to overexpression of oncogenes such as activated HRAS, proposed to be a defensive response to 'oncogenic stress' (overstimulation of mitogenic pathways such as the MAPK pathway) (Collado and Serrano, 2006).

The absence of detectable p53 or p21 in most benign naevi, using protocols that did stain these proteins in other lesions, similarly makes it very unlikely that their senescence is p53dependent. Again, the senescence in naevi may be a novel form of senescence. Otherwise it seems most likely that it is p16-dependent senescence, since most cells in all benign naevi did express p16, and since human melanocytes normally show p16-dependent senescence in culture. It is unclear, however, why p16 cannot be immunostained in all cells of benign naevi, if it mediates their growth arrest. Several reasons seem possible. Firstly, the sensitivity of immunostaining is limited, and the levels of p16 are clearly variable, so it may be that p16 is actually present in all naevus cells and is able to arrest growth at relatively low levels. Secondly, there may be cell-cell interactions such as secretion of growth inhibitors by senescent cells, that secondarily arrest p16-non-expressing cells - and induce senescence marker acidic $\beta$-galactosidase, which both we and Michaloglou et al typically observed in all cells of naevi. Thirdly, this may be an effect of the widespread chromatin remodelling and gene silencing that can result from high activation of RB-family proteins (Narita et al, 2003). Cells may become so transcriptionally inactive that p16 itself, although initially expressed, becomes silenced in some cells, growth stasis being maintained by silencing of genes required for cell proliferation.

We proposed previously (Bennett, 2003) that dysplastic naevi might represent escape from p16-dependent senescence and

Figure 5 Effects of transfected $B R A F$ sequences on cultured normal human melanocytes. Assays were performed 10 days $(\mathbf{A})$ or 5 days $(\mathbf{B}, \mathbf{C})$ after transfection of cells. (A) Expression of growth-related proteins as shown by immunoblotting. (NHM), normal human melanocytes, transfected with the vector only (CONT, control), or with ${ }^{W T} B R A F$ (WT) or ${ }^{V 600 E}$ BRAF (VE) sequences. WM266-4 human melanoma cells and HeLa cells were used as positive controls for p21 and p16 expression, respectively. mBRAF: detection of Myc tag present on both WT and VE transfected BRAF sequences. PERK: phospho-ERK as a marker of active MAPK signalling. ERK: total ERK protein. (B) Counts of nuclei positive for proliferative marker Ki67 or for p 16, by immunostaining of cells transfected with vector only (0), WT BRAF or ${ }^{600 E_{B}}$ BRAF. Means and SEM are shown. p I 6 positivity is shown in both the total culture including any nontransfected cells, and (*) as \% of double-stained cells positive for exogenous BRAF (Myc tag), that also showed nuclear p I6. After only 5 days, Ki67 positivity was significantly reduced in the total culture with ${ }^{V 600 E} B R A F(P<0.05)$.

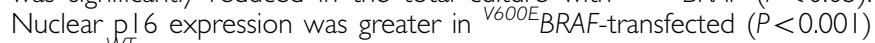
but not ${ }^{W T}$ BRAF-transfected cells relative to control (whole culture), and in ${ }^{{ }^{6} 600 E_{B R A F}}$-expressing cells (over $45 \%$ positive for $\mathrm{p} / 6$ ) relative to ${ }^{W T}$ BRAFexpressing cells $(P<0.00 \mathrm{I})$. Significance testing was by Student's t-test. $(\mathbf{C})$ Typical examples of immunostained cells, showing nuclear p 16 staining in melanocytes expressing ${ }^{{ }^{6} 00{ }_{B}}$ BRAF but not ${ }^{W T}$ BRAF. Upper label on each panel indicates transfected sequence, lower label indicates stain. Both BRAF proteins were immunostained with anti-Myc tag. This gave no staining in cultures transfected with the vector only (not shown). DAPI staining showed nuclei. 
attainment of p53-dependent senescence (or telomeric crisis (Sharpless and DePinho, 2004)). Here, we report that p16 expression is indeed patchy and sometimes cytoplasmic in dysplastic naevi, but generally p53 is expressed only in a few areas, and often without $\mathrm{p} 21$. Thus, dysplastic areas of naevi may sometimes be still proliferating rather than in any kind of senescence. We also suggested that primary melanoma cells have emerged from senescence and immortalised (Bennett, 2003). Previous evidence for this includes the obvious property that melanoma cells proliferate, and the detection of telomerase activity in most melanomas and not in naevi (Glaessl et al, 1999; Rudolph et al, 2000). Explanted melanoma cells are not reported to senesce (Herlyn et al, 1985), growing so readily that thousands of melanoma cell lines exist. From immunohistochemistry of parallel sections, we now report that senescence effectors p16, p21, p53 and overexpressed CHK2 are undetectable in substantial regions of all melanomas, while a few areas usually expressed all of these, often in association with large, pigmented and/or multinucleate cells. Such areas may represent residual senescent regions (naevus), part of the clonal evolution of the tumours.

p16 protein at times appeared cytoplasmic-only. This may sometimes indicate a dysfunctional, mutant protein, as it does in the naevus from the p16-mutant patient (Huot et al, 2002), although other factors such as other RB pathway alterations may affect p16 location. More commonly p16 was absent from much of a melanoma section, especially in VGP lesions; this can be explained partly by the high rate of p16 deletion in primary melanomas (Curtin et al, 2005), but may also involve other mechanisms, since the said deletions are often not homozygous. In some cases, p53-expressing lesional cells in the dermis were surrounded by lymphocytes and melanophages. Among other possible explanations, death of lesional melanocytes may provoke an inflammatory reaction. This is plausible: lesional melanocytes strongly expressing p53 are likely to be p16/RB-deficient, and cultured p16-deficient melanocytes tend to apoptose in the absence of keratinocytes (Bennett, 2003; Sviderskaya et al, 2003).

Strong genetic evidence that the proliferative arrest in naevi can be p16-dependent is provided by the frequent association of germline p16 defects with larger, more numerous and dysplastic naevi (Gruis et al, 1995; Bennett, 2003), as well as with melanoma susceptibility. Here, we report unusual p53 and p21 expression in a large naevus from a patient who lacks functional p16 and whose cells thus cannot undergo p16-dependent senescence. It is possible that this naevus was undergoing or approaching p53-dependent senescence, although not proven. As the p16 sequence is a melanoma susceptibility gene (Gruis et al, 1995; Hayward, 2003), p16 must somehow impede melanoma development. However, not all melanoma families with p16 mutations do have abnormally large naevi (Hayward, 2003; Kefford et al, 2004); likewise members

\section{REFERENCES}

Bandyopadhyay D, Timchenko N, Suwa T, Hornsby PJ, Campisi J, Medrano EE (2001) The human melanocyte: a model system to study the complexity of cellular aging and transformation in non-fibroblastic cells. Exp Gerontol 36: 1265-1275

Bartkova J, Lukas J, Guldberg P, Alsner J, Kirkin AF, Zeuthen J, Bartek J (1996) The p16-cyclin D/Cdk4-pRb pathway as a functional unit frequently altered in melanoma pathogenesis. Cancer Res 56: 5475-5483

Bastian BC (2003) The longer your telomeres, the larger your nevus? Am J Dermatopathol 25: 83-84

Bennett DC (2003) Human melanocyte senescence and melanoma susceptibility genes. Oncogene 22: 3063-3069

Bennett DC (2006) Familial melanoma genes, melanocyte immortalization and melanoma initiation. In: Melanocytes to Melanoma: The Progression to Malignancy, Hearing VJ, Leong SPL (eds) New Jersey: Humana Press

Bennett DC, Bridges K, McKay IA (1985) Clonal separation of mature melanocytes from premelanocytes in a diploid human cell strain: bearing the same p16 mutation within a single family can vary as to whether they have large naevi (Gruis et al, 1995), which suggests variation between humans in the contribution of p16 compared to other genetic (or environmental) components in determining mole size distribution. This may involve redundancy with some functionally related molecule, as suggested (Gruis et al, 1995). The present report together with that of Michaloglou et al (2005) provide persuasive evidence that the growth arrest in naevi is cell senescence. This seems to be a highly efficient barrier to melanoma, since naevi are far more common than melanoma. As mediators of p53-dependent senescence are not found in benign naevi, whereas p16 is detected in $100 \%$ of these lesions and in most cells within the lesions, it seems likely that p16 at least contributes to establishing senescence in naevi. This provides an attractive possible mechanism by which the $\mathrm{p} 16 / \mathrm{RB}$ pathway could suppress melanoma following mitogenic mutations like $B R A F$ activation. It was reported recently that $\mathrm{RB}$ pathway ablation in combination with three other genetic alterations in human melanocytes (NRAS activation, p53 activation and hTERT expression) is necessary and sufficient to produce melanoma-like lesions in a reconstituted skin-xenograft model (Chudnovsky et al, 2005), in good agreement with our genetic model (Bennett, 2003).

There is much potential for further exploration of the possibility of cell senescence in vivo and as a real cancer barrier. Cancers grow progressively, but various lesions such as cysts and thyroid adenomas show self-limiting growth. Perhaps cell senescence may occur in many organ types following initial mutations, as supported by recent reports from animal models (Braig et al, 2005; Collado et al, 2005). This would help to explain why p16 and p53 are such universal tumour suppressors, and it now seems important to investigate this possibility more widely.

\section{ACKNOWLEDGEMENTS}

We are greatly indebted to Chris Jones for provision of retroviral vectors, Simon Hill and Jane Bond for expert technical assistance, Ray Boissy for the HM303CN melanocyte culture, Veronique Bataille and Robin Russell-Jones for provision of sections from the patient with p16 mutations, Simon Forbes for providing figures from COSMIC for uncultured lesions, Barry Powell for facilitating the provision of unfixed naevus specimens, Alastair MacKenzie Ross for p16 immunocytochemistry of some lesions, and Lucy Hill for cytogenetic analysis of cultures. 1 VCG-S was supported by European Commission FP5 contract QLK4-1999-01084 and SCC by a British Council Commonwealth Scholarship and a UNESCO short-term fellowship. spontaneous and induced pigmentation of premelanocytes. J Cell Sci 77: $167-183$

Bennett DC, Medrano EE (2002) Molecular regulation of melanocyte senescence. Pigment Cell Res 15: 242-250

Bodnar AG, Quellette M, Frolkis M, Holt SE, Chiu CP, Morin GB, Harley CB, Shay JW, Lichtensteiner S, Wright WE (1998) Extension of life-span by introduction of telomerase into normal human cells. Science 279: 349-352

Braig M, Lee S, Loddenkemper C, Rudolph C, Peters AH, Schlegelberger B, Stein H, Dorken B, Jenuwein T, Schmitt CA (2005) Oncogene-induced senescence as an initial barrier in lymphoma development. Nature 436: $660-665$

Chudnovsky Y, Adams AE, Robbins PB, Lin Q, Khavari PA (2005) Use of human tissue to assess the oncogenic activity of melanoma-associated mutations. Nat Genet 37: 745-749

Clark WH (1991) Tumour progression and the nature of cancer. Br J Cancer 64: $631-644$ 
Clark WH, Elder DE, Guerry D, Epstein MN, Greeve MH, Van Horn M (1984) A study of tumor progression: the precursor lesions of superficial spreading and nodular melanoma. Hum Pathol 15: 1147-1165

Collado M, Gil J, Efeyan A, Guerra C, Schuhmacher AJ, Barradas M, Benguria A, Zaballos A, Flores JM, Barbacid M, Beach D, Serrano M (2005) Tumour biology: senescence in premalignant tumours. Nature 436: 642

Collado M, Serrano M (2006) The power and the promise of oncogeneinduced senescence markers. Nat Rev Cancer 6: 472-476

Curtin JA, Fridlyand J, Kageshita T, Patel HN, Busam KJ, Kutzner H, Cho KH, Aiba S, Brocker EB, LeBoit PE, Pinkel D, Bastian BC (2005) Distinct sets of genetic alterations in melanoma. $N$ Engl J Med 353: $2135-2147$

d'Adda di Fagagna F, Reaper PM, Clay-Farrace L, Fiegler H, Carr P, Von Zglinicki T, Saretzki G, Carter NP, Jackson SP (2003) A DNA damage checkpoint response in telomere-initiated senescence. Nature 426: $194-198$

Danos O, Mulligan RC (1988) Safe and efficient generation of recombinant retroviruses with amphotropic and ecotropic host ranges. Proc Natl Acad Sci USA 85: 6460-6464

Davies H, Bignell GR, Cox C, Stephens P, Edkins S, Clegg S, Teague J, Woffendin H, Garnett MJ, Bottomley W, Davis N, Dicks E, Ewing R, Floyd Y, Gray K, Hall S, Hawes R, Hughes J, Kosmidou V, Menzies A, Mould C, Parker A, Stevens C, Watt S, Hooper S, Wilson R, Jayatilake H, Gusterson BA, Cooper C, Shipley J, Hargrave D, Pritchard-Jones K, Maitland N, Chenevix-Trench G, Riggins GJ, Bigner DD, Palmieri G, Cossu A, Flanagan A, Nicholson A, Ho JW, Leung SY, Yuen ST, Weber BL, Seigler HF, Darrow TL, Paterson H, Marais R, Marshall CJ, Wooster $\mathrm{R}$, Stratton MR, Futreal PA (2002) Mutations of the BRAF gene in human cancer. Nature 417: 949-954

Dimri GP, Lee X, Basile G, Acosta M, Scott G, Roskelley C, Medrano EE, Linskens M, Rubelj I, Pereira-Smith O, Peacocke M, Campisi J (1995) A biomarker that identifies senescent human cells in culture and in aging skin in vivo. Proc Natl Acad Sci USA 92: $9363-9367$

Forbes S, Clements J, Dawson E, Bamford S, Webb T, Dogan A, Flanagan A, Teague J, Wooster R, Futreal PA, Stratton MR (2006) COSMIC 2005. Br J Cancer 94: $318-322$

Gilchrest BA, Treloar V, Grassi AM, Yaar M, Szabø G, Flynn E (1986) Characteristics of cultivated adult human nevocellular nevus cells. J Invest Dermatol 87: $102-107$

Glaessl A, Bosserhoff AK, Buettner R, Hohenleutner U, Landthaler M, Stolz W (1999) Increase in telomerase activity during progression of melanocytic cells from melanocytic naevi to malignant melanomas. Arch Dermatol Res 291: $81-87$

Gray-Schopfer VC, Bennett DC (2006) The genetics of melanoma. In: The Pigmentary System. Physiology and Pathophysiology, Nordlund JJ, Boissy RE, Hearing VJ, King RA, Oetting WS, Ortonne JP (eds) New York: Oxford University Press

Gruis NA, van der Velden PA, Sandkuijl LA, Prins DE, Weaver-Feldhaus J, Kamb A, Bergman W, Frants RR (1995) Homozygotes for CDKN2 (p16) germline mutation in Dutch familial melanoma kindreds. Nat Genet 10: $351-353$

Halaban R, Ghosh S, Duray P, Kirkwood JM, Lerner AB (1986) Human melanocytes cultured from nevi and melanomas. J Invest Dermatol 87: $95-101$

Halbert CL, Demers GW, Galloway DA (1991) The E7 gene of human papillomavirus type 16 is sufficient for immortalization of human epithelial cells. J Virol 65: 473-478

Hayward NK (2003) Genetics of melanoma predisposition. Oncogene 22: $3053-3062$

Healy E, Belgaid C, Takata M, Harrison D, Zhu NW, Burd DA, Rigby HS, Matthews JN, Rees JL (1998) Prognostic significance of allelic losses in primary melanoma. Oncogene 16: 2213-2218

Herlyn M, Balaban G, Bennicelli J, Guerry D, Halaban R, Herlyn D, Elder DE, Maul GG, Steplewski Z, Nowell PC, Clark WH, Koprowski H (1985) Primary melanoma cells of the vertical growth phase: similarities to metastatic cells. J Natl Cancer Inst 74: 283-289

Huot TJ, Rowe J, Harland M, Drayton S, Brookes S, Gooptu C, Purkis P, Fried M, Bataille V, Hara E, Newton-Bishop J, Peters G (2002) Biallelic mutations in $\mathrm{p} 16^{\mathrm{INK} 4 \mathrm{a}}$ confer resistance to Ras- and Ets-induced senescence in human diploid fibroblasts. Mol Cell Biol 22: $8135-8143$

Hussein MR, Wood GS (2002) Molecular aspects of melanocytic dysplastic nevi. J Mol Diagn 4: 71-80
Kefford RF, Mann GJ, Newton Bishop J (2004) Genetic predisposition to melanoma. In: Textbook of Melanoma, Thompson JF, Morton DL, Kroon BBR (eds) pp 56-64. New York: Martin Dunitz

Keller-Melchior R, Schmidt R, Piepkorn M (1998) Expression of the tumor suppressor gene product $\mathrm{p} 16^{\mathrm{INK} 4}$ in benign and malignant melanocytic lesions. J Invest Dermatol 110: $932-938$

Kiyono T, Foster SA, Koop JI, McDougall JK, Galloway DA, Klingelhutz AJ (1998) Both $\mathrm{RB} / \mathrm{p} 16^{\mathrm{INK} 4 \mathrm{a}}$ inactivation and telomerase activity are required to immortalize human epithelial cells. Nature 396: 84-88

Kurz DJ, Decary S, Hong Y, Erusalimsky JD (2000) Senescence-associated $\beta$-galactosidase reflects an increase in lysosomal mass during replicative ageing of human endothelial cells. J Cell Sci 113(Part 20): 3613-3622

Michaloglou C, Vredeveld LC, Soengas MS, Denoyelle C, Kuilman T, van der Horst CM, Majoor DM, Shay JW, Mooi WJ, Peeper DS (2005) $\mathrm{BRAF}^{\mathrm{E} 600}$-associated senescence-like cell cycle arrest of human naevi. Nature 436: $720-724$

Minwalla L, Zhao Y, Le Poole IC, Wickett RR, Boissy RE (2001) Keratinocytes play a role in regulating distribution patterns of recipient melanosomes in vitro. J Invest Dermatol 117: $341-347$

Mooi WJ (1997) The dysplastic naevus. J Clin Pathol 50: 711-715

Mooi WJ, Peeper DS (2002) Pathogenesis of melanocytic naevi: growth arrest linked with cellular senescence? Histopathol 41(Suppl 2): $120-146$

Narita M, Nunez S, Heard E, Narita M, Lin AW, Hearn SA, Spector DL, Hannon GJ, Lowe SW (2003) Rb-mediated heterochromatin formation and silencing of E2F target genes during cellular senescence. Cell 113: $703-716$

Pollock PM, Harper UL, Hansen KS, Yudt LM, Stark M, Robbins CM, Moses TY, Hostetter G, Wagner U, Kakareka J, Salem G, Pohida T, Heenan P, Duray P, Kallioniemi O, Hayward NK, Trent JM, Meltzer PS (2003) High frequency of BRAF mutations in nevi. Nat Genet 33: $19-20$

Ramirez RD, Morales CP, Herbert BS, Rohde JM, Passons C, Shay JW, Wright WE (2001) Putative telomere-independent mechanisms of replicative aging reflect inadequate growth conditions. Genes Dev 15: $398-403$

Robinson MJ, Cobb MH (1997) Mitogen-activated protein kinase pathways. Curr Opin Cell Biol 9: 180-186

Rudolph P, Schubert C, Tamm S, Heidorn K, Hauschild A, Michalska I, Majewski S, Krupp G, Jablonska S, Parwaresch R (2000) Telomerase activity in melanocytic lesions: a potential marker of tumor biology. $\mathrm{Am} \mathrm{J}$ Pathol 156: 1425 - 1432

Scott MC, Wakamatsu K, Ito S, Kadekaro AL, Kobayashi N, Groden J, Kavanagh R, Takakuwa T, Virador V, Hearing VJ, Abdel-Malek ZA (2002) Human melanocortin 1 receptor variants, receptor function and melanocyte response to UV radiation. J Cell Sci 115: 2349-2355

Sharpless NE, DePinho RA (2004) Telomeres, stem cells, senescence, and cancer. J Clin Invest 113: $160-168$

Sherr CJ (2001) The INK4a/ARF network in tumour suppression. Nature Rev Mol Cell Biol 2: 731 - 737

Stewart SA, Ben Porath I, Carey VJ, O'Connor BF, Hahn WC, Weinberg RA (2003) Erosion of the telomeric single-strand overhang at replicative senescence. Nat Genet 33: $492-496$

Straume O, Smeds J, Kumar R, Hemminki K, Akslen LA (2002) Significant impact of promoter hypermethylation and the $540 \mathrm{C}>\mathrm{T}$ polymorphism of CDKN2A in cutaneous melanoma of the vertical growth phase. Am J Pathol 161: 229-237

Sviderskaya EV, Gray-Schopfer VC, Hill SP, Smit NP, Evans-Whipp TJ, Bond J, Hill L, Bataille V, Peters G, Kipling D, Wynford-Thomas D, Bennett DC (2003) p16/cyclin-dependent kinase inhibitor 2A deficiency in human melanocyte senescence, apoptosis, and immortalization: possible implications for melanoma progression. J Natl Cancer Inst 95: $723-732$

Talve L, Sauroja I, Collan Y, Punnonen K, Ekfors T (1997) Loss of expression of the $p 16^{I N K 4} / C D K N 2$ gene in cutaneous malignant melanoma correlates with tumor cell proliferation and invasive stage. Int J Cancer 74: 255-259

Von Zglinicki T, Saretzki G, Ladhoff J, d'Adda dF, Jackson SP (2005) Human cell senescence as a DNA damage response. Mech Ageing Dev 126: $111-117$

Wellbrock C, Ogilvie L, Hedley D, Karasarides M, Martin J, NiculescuDuvaz D, Springer CJ, Marais R (2004) V599EB-RAF is an oncogene in melanocytes. Cancer Res 64: 2338 -2342

Wynford-Thomas D (1999) Cellular senescence and cancer. J Pathol 187: $100-111$ 